\title{
Cinnamomum zeylanicum Bark Extract
}

National Cancer Institute

\section{Source}

National Cancer Institute. Cinnamomum zeylanicum Bark Extract. NCI Thesaurus. Code C107289.

The oil extracted from the bark of Cinnamomum zeylanicum. Cinnamon bark oil has antibacterial and antifung al properties but is an irritant to skin. It is used primarily in aromatherapy. 